\title{
The Centrality of the Language Question in the Decolonization of Education in Africa ${ }^{1}$
}

\section{Kwesi Kwaa Prah}

\section{Introduction}

In the last two years (2016-2017), the challenge of decolonizing education in Africa has found voice, expressed with a great deal of emotion, noise and fanfare by university students in South Africa. Noticeably, the initial fervour of the call appears to have considerably abated. What happens next? Early this year, 2017, during a visit to the University of Venda, one of the Deans remarked to me that; 'we have been here before, in the 1990s, after the formal end of Apartheid, there had been calls in the university for changes which amounted to the same thing, as the calls for decolonization that are being made now.' Nothing happened then. A decade and a half later, there is again danger of the current enthusiasm of the times petering out.

A good part of the lack of application in addressing the issue is due to the fact that, although the idea of decolonizing education is immensely suggestive, understanding what this should mean and entail, beyond superficialities and resounding mantras, remains for many vague and analytically unclear. Oftentimes, there are sweeping, radical, but empty calls which equate almost everything which does not sound directly African as Eurocentric anathema. The decolonization of knowledge and education does not and should not mean a philistine rejection of Western-derived knowledge and argumentation. It suggests divesting the content of education of the inherited Western vestment. It signifies that we must construct knowledge which speaks to our cultural and linguistic distinctions. We must stop looking at ourselves with the optics of outsiders. It means in short that education must directly address the issue of societal relevance. This implies in practice

${ }^{1}$ Keynote Address: 8 th University of Zululand, Humanities and Social Science Conference, 18th - 20th October, 2017. 
modifications in the existing class basis of knowledge production and the deployment of knowledge. I have elsewhere indicated that there is need for substantive identification of the component features, in terms of concepts, terminologies, methodologies and disciplinary justifications which need interrogation and specific address (Prah 2017). This requires in-depth examination of what precisely needs to be revised, reformed, altered, overhauled or removed in the various disciplinary pursuits in the academy. Some of these inadequacies have in the past been fingered (Ibid.).

For example, in our education systems, the periodization of African history runs from the precolonial, colonial and post-colonial periods. This colonialist historiography affects other disciplines in the social sciences and humanities. The implication of this periodization format is that, the whole of African history is pigeon-holed into three slots; each of them conceptually revolving around the colonial encounter. The arrival of the West in general and colonialism in particular are treated as the most pivotal features in the whole of African history. This periodization schema locks us into Western colonial history and reduces us to the footnotes of this Western colonial history. It places Africans on the borders of this history as luckless add-ons and innately rationalizes and justifies Western imperial ascendancy. This tri-layered periodization is actually an outline of Western history in Africa. Africans are through this schema made oblivious products of the West. As a conceptual tool, this representation is so analytically overriding that as a scientific narrative it completely disables Africans of any option for free historical agency. Apart from its unambiguous Eurocentric bias, it has also critical scientific incongruities (Ibid) ${ }^{2}$. Another anomaly is that, the ghettoization of African

${ }^{2}$ I add that, 'The only period in this tri-layered history which can in some form be given authentic chronology, is the colonial period. The precolonial period which accounts for over $90 \%$ of African history is fossilized and rendered analytically inert. For now, it is cognitively unyielding and devoid of any attempt or possibility for further detailed chronological differentiation. When reference is made to the precolonial period in African history, we do not know where we stand, it could be a hundred years, two hundred years, a thousand years or ten thousand years. The construction of an "ethnographic present" the putative description of a culture to establish its features prior to Western contact - in fact only invents an ahistorical image of the past where sociocultural realities with diverse depth in time are treated and regarded without 
Studies as a separate area of quasi-disciplinary concentration in African universities implies that the rest of the other schools, departments and faculties in our universities do not study African realities (Ibid). Equally absurd is the notion of African literature in European languages (Ibid). All these scholastic irrationalities in the structure and substance of African education point to the fact that contemporary African scholarship is riddled with Eurocentric paradigms and lacks the projection of sovereignty in our endeavours. The result is that we have Western universities in Africa, not African universities in Africa.

In this lecture/address I want specifically to look at the significance of language in the discussion of the decolonization of education in Africa. My argument will be that it should be the starting point and the pre-eminent feature which needs to be engaged, if any success to the efforts of decolonizing education is to be registered. Without address of the language question, any attempt at the 'decolonization of education' is futile.

\section{Locating Language}

In the larger order of nature, homo sapiens sapiens distinguishes him/herself from the rest of the animal kingdom through the production and reproduction of culture; in terms of the entirety of both the tangible and intangible expression of the human genius. No other animal produces culture as a continuous, ceaselessly changing, generationally transferred and constitutionally altered product. The tangible products are for all to see as an assemblage of the creation of homo faber. The intangibles; language, religion and ritual, customary practices and mores, values, beliefs and tastes are incorporeal, but real in the roles they play in our lives. Of all these material and non-material constituents of culture, language is the most decisive constituent of the totality.

historical differentiation. It implicationally assumes a static, "pre-contact/ precolonial" view of African societies. The cultural traits that were found on the eve of colonialism are treated as if they were timeless and reified phenomena that have no origins in specific periods or junctions in African history. How do we methodologically negate this a-historicism embedded in this Eurocentric periodization scheme? We must in the first instance conceptually place Africans in the centre of history in general and African history in particular'. 
It is the central pillar on which the edifice of the reality we call culture is constructed.

Language is the transactional grid through which what is recognized and knowable, presented vocalically or represented in systematically organized symbols of sounds is shared as a collectively held medium on which basis we conduct rational social interaction. Its groundwork lies in the underlying logical order which rhymes with natural processes. Thus its ultimate foundations transcend vocalic expressions and can attain and be represented as abstract mathematical notation. Steiner makes this point well when he says that, when mathematics turned modern and began exhibiting its vast scope for autonomous conception ... translation become less and less possible;

The great architectures of form and meaning conceived by Gauss, Cauchy, Abel, Cantor, and Weierstrass recede from language at an ever accelerated pace. Or rather, they require and develop languages of their own as articulate and elaborate as those of verbal discourse. And between these languages and that of common usage, between the mathematical symbol and the word, the bridges grow more and more tenuous, until at last they are down. Between verbal languages, however remote in setting and habits of syntax, there is always the possibility of equivalence, even if actual translation can only attain rough and approximate results. The Chinese ideogram can be transposed into English by paraphrase or lexical definition. But there are no dictionaries to relate the vocabulary and grammar of higher mathematics to those of verbal speech. ... I have watched topologists, knowing no syllable of each other's language, working effectively together at a blackboard in the silent speech common to their craft (Steiner 1970:14-15).

This silent language of mathematics to which Steiner makes reference is indeed language which goes beyond vocalic expression; language at its barest and most unadorned. It is language set in the stark nakedness of the natural order; the order on which the primary logic of the cosmos is founded; the laws governing materiality. Thus, technically it should be possible to reduce all vocalic language into non-vocalic notational mathematical expression. It is the height of abstraction to which the usage of sounds become irrelevant to our understanding of the logical argumentation underlying notational mathematics. 
For the present, it is extremely difficult, but in my estimation not inconceivable, to move in the opposite direction of expressing, for example, topological notation in sound expressions. Its phonological range, phonemic composition and lexical complexity may be quite unlike anything we currently know, as verbal language.

Another interesting case is musical notations. These have varying histories, different symbolic representations in different cultures, but which through conventions, share universal meanings; in each instance they represent systems of logic which can be mathematically constructed and are therefore to varying degrees predictable. Different types of music and different notational forms have varying logical orders which are systematic in as far as the specific types of music and variant notational conventions are concerned.

All languages are learnt, although as Chomsky, has explained; the underlying 'cognitive capacity' to acquire a speech form is based on an inherent biologically founded human development which enables the operation of a 'universal grammar'; 'the system of principles, conditions, and rules that are elements or properties of all human languages not merely by accident but by necessity ... biological, not logical, necessity' (Chomsky 1975:29). The fact that languages are learnt, by extension, means that culture is learnt. But the capacity for this is founded on the biological complexities of homo sapiens sapiens. In other words, the human language facility is not exclusively experientially drawn. It must be largely inborn. It is not inferred from instructive examples but 'triggered' by the environment to which the language learner is exposed.

It has been argued that; the decisive step in the advancement from ape to man ensued when tree-climbing led to the variation in the functionality of the ape's hands and feet, standing upright, thus leaving the hands free when walking, i.e. the evolutionary emergence of bipedalism and hence the facilitation of an upright carriage. The fore-limbs as hands became in time specialized for different and novel purposes like eating, the fabrication of shelter, and physical defence; the ability to 'grasp cudgels.' Yet most importantly, 'no ape's hand has ever fashioned the crudest stone knife... the development of labour necessarily helped to bring the members of society closer together by increasing cases of mutual support and joint activity, and by making clear the advantage of this joint activity to each individual. In short, men in the making arrived at the point where they had something to say to each other. Necessity created the organ; the undeveloped larynx of the ape was 
slowly but surely transformed by modulation to produce constantly more developed modulation, and the organs of the mouth gradually learned to pronounce one articulate sound after another. Comparison with animals proves that this explanation of the origin of language from and in the process of labour is the only correct one. ... First labour, after it and then with it speech - these were the two most essential stimuli under the influence of which the brain of the ape gradually changed into that of man' (Engels 1950::7 - 13). The ability to produce labour and speech provided the means to create culture.

Thus, historically, in the social evolution of humanity, the two most consequential factors in human progress have been labour and language; as humans we are unique in two ways, we are tool-bearing and talkative animals (Bodmer 1943:17). These two conditions have been however contingent on the production and reproduction of human life itself. But this relationship is dialectical, or more simply stated, interdependent. Labour has determined the material basis for the maintenance of human life and the proliferation of the species, while language has been the prime cultural product of humanity which has enabled the creation of a social communication system on which the rest of culture is constructed. Language carries and expresses culture.

\section{Defining Education}

Language is the primary tool for education and education is at heart a system of inculcating ideas and bequeathing the heritage of knowledge and cultural practices in a given society to its people. In general, it is a process that starts as early as possible in the human life-cycle, when mental fertility is in its most active and primed condition; as soon as the young members of society are deemed to have the ability to respond meaningfully to teaching and systematic influence.

In sociological usage, education cannot be separated from socialization. The effect of education is to adapt members of the society, steadily, to the norms, beliefs and usages of a given culture. But, up and above this, an educational system seeks to teach its target-group skills and techniques, which enable such groups to operate adeptly in the production and reproduction of life in the society and the circumstances surrounding this. In this sense, there is a degree of specificity in the content of education for any society. Education answers to needs and conditions in specific societies. For education to be effective in addressing societal needs, as societal conditions 
change, the structure, content and form of education systems must also change. Issues of societal relevance are thus important in the formulation and development of educational systems and content.

Decolonizing education implies a search for a new system and content for new societal challenges. There are subjects for which the implication of decolonization is relatively minimal. These are in the natural and hard sciences. In the social sciences and humanities, the issue is much bigger. But whatever area of knowledge production we consider, the language question remains fundamentally germane. What is a leading and treasured value in one society may have a different premium in the next. No educational system can serve all societies all the time. No educational system has total universal value. This implies for example that, to learn someone else's history when you do not know yours is a colonial or neo-colonial condition. It is equally true that, in any society where the language or languages of minorities or foreigners are languages of power, official business and education there is in place a colonial, neo-colonial or internal colonial situation.

It is now common knowledge that education is best conducted and most effective when undertaken in the mother-tongue; that where different cultures and people huddle together in common citizenship a spacious multiculturalist and multi-lingual approach to education allows better the cultivation of tolerance and coexistence. Furthermore, we know that the acquisition of knowledge is most successfully developed when it builds on what people already know, that is, knowledge that is indigenous. Indigenous knowledge is knowledge that is inherited by a language-group, knowledge which is rooted in the culture and history of the people; it is expressed in the language of that particular cultural group. It is impossible to conceive of a society with some historical depth and cultural peculiarities, which is bereft of any indigenous and societally relevant knowledge. Naturally, the members of a particular society refer and relate to such knowledge in their social interaction through the indigenous languages.

In neocolonial societies, the colonially imposed language of the colonizer is maintained in the post-colonial period. The educational process, preserves the pre-eminence of the language of the colonizer, this way it persists in bypassing indigenous knowledge systems and continues to construct and impose novel ideas without respect, reference and acknowledgement of the viability of the knowledge which Africans already have, and which has been generationally passed on over the centuries. One of the correctives which need 
to be made in African educational systems as part of the effort to decolonize education is the acceptance of the need to build on African indigenous knowledge systems with these latter as credible points of departure. New and modern knowledge is best absorbed if adapted to the cultural and knowledge basis of the people, the speech-community or communities concerned.

Since language captures and describes everything in culture, it reflects continuously technological transformations and developmental changes in societies. Knowledge which is organically embedded in the language of a culture, whether originally adapted from an extraneous cultural and societal source or homegrown and autonomously developed, is indigenous to the speech community who 'own' the language. In short, indigenous knowledge is quintessentially located in the language of a specific culture. It is knowledge generated, used and developed by a people. It is not limited to indigenously and autonomously produced knowledge; it can include knowledge originating from elsewhere that has been linguistically internalized and 'domesticated' by local people through local processes of learning, testing, adaptation and absorption. Although, indigenous knowledge is rooted in and derives from local practices; it is an open system. What this implies is that we can and indeed do add to our indigenous fund of knowledge inputs from outside our cultural systems. All societies do this, but for the process to reach the masses, and be owned by the masses, it must be integrated into the languages of the masses. Then, it becomes part of the fund of the culture in question. Another way of making the point is that if we learn in languages other than the languages of our societies, the languages closest to our hearts and minds, culturally that knowledge does not automatically enter our cultures. Such knowledge enters our indigenous knowledge systems when we translate such data into our languages. Using a language means entering the cultural world which that language represents. It is through language that cultures are developed.

Educational systems generally reflect the dominant thinking and value system in a society, and are expressions of the society's interests as perceived by the ruling or influential groups in the society, in a given historical period. In other words, educational systems are not constructed to negate the values or interests of the dominant groups in the society. The educated are expected to be products that adjust to the value systems that prevail. Conformity and social functionality are therefore implicit goals of educational systems, although, history is replete with examples of individuals and groups whose historical records demonstrate that revolt against authority and the challenge of canon is 
often the intellectual hallmark of the best educated.

The relevance of African culture to any system of effective education in Africa needs to be particularly emphasised not because of its bearing on the development of the politically glorified populist notion of a 'national culture' but because of the logic of building on what people have with respect to their history, and not denying their histories and cultures and operating as if they are entirely creations of colonialism. Obviously, cultural divergences exist not only synchronically but also diachronically. But, by and large, Colonialism did not build education on our indigenous knowledge heritage, rather, it usurped, undermined and dismantled this.

\section{Current Context; African Elites in Neocolonial States}

It needs to be emphasized that, the issue of the decolonization of education which has come forcefully to the fore and become the immediate conundrum in South African education is not restricted to the South African realities. It is applicable throughout the whole of former colonial Africa. It is indeed even more remarkable that many are countries which have decades of postcolonialism behind them, without having ever addressed the question of the decolonization of education in any serious way. There are some countries on this continent which have hardly voiced any disputation with the structure and content of education as a colonial legacy. In the light of this, current South African preoccupations with the issue and the search for answers are socially pregnant and noteworthy concerns not only for South Africa, but for the whole of post-colonial Africa.

The matter raises a number of queries. Some of these are; what are we doing in response to the issue? Are we going to address the questions attendant on the need to decolonize education in South Africa or are we, like most of the other countries in Africa, going to eventually turn a blind eye to the issue and allow the persistence of the legacy of colonialism in our educational life to linger on? Will African post-colonial elites, as they are currently constituted, ever rise to the occasion, towards the decolonization of education? What do we precisely mean by, the decolonization of education? What concrete steps do we need to make towards this objective?

We know that for most of the emergent countries of post-colonial Africa, with the end of colonialism, the new African states in fact seamlessly morphed into neo-colonial order. The latter is a condition in which the 
assumption of sovereignty is for all intents and purposes a hoax; where meaningful power and influence, in most respects, particularly in the economic, political and cultural spheres, are determined by external sources, interests and forces (invariably the former colonial masters). In Africa after colonialism, a new principally native elite came into power, but by and large, in almost all areas of human endeavour, the heritage of the colonial structure and experience was passed on without serious interrogation, self-examination and transformation. No real attempt was made anywhere to bury the denationalizing effects of colonialism. These new elites were, ideologically and educationally, native replicas of the colonial administrators. In the decades of post-colonialism they have effortlessly reproduced themselves. In the settler-colonial areas, the settler-ruling classes have been joined as junior partners by indigenous elements.

The nativization of colonial and post-colonial elites, with hosts of bureaucratic and political offices, national anthems, flags and other emblems of novel statehood to match, provided a gloss of freshness and newness which is only skin-deep; more appearance than reality. As creatures of a successful colonial project, the new elites of these colonially-engendered states were in vision trapped by the perspectives of the colonial masters.

\section{Imperialism and Culture}

The effects of colonialism on the native cultures of the colonized was to dismantle or dismiss them as atavistic representations of human progress. As Horne idiomatically described it; 'In these colonies the imperialists, in the name of preventing anarchy, caused it. Taking advantage of the native's powerlessness, they imposed their own civilization within the native's civilization but as something apart... attempting to change it but mocking it and eroding it, walking through it as if it were not there, and pulling off any bits that got in the way' (Horne 1969:108).

Everywhere colonialism was established, it abused the culture of the indigenes and grafted upon it cultural forms and structures which enabled the control and assimilation of native peoples. Principal amongst these were language and religion. These have been the most successful instruments of dislocation and assimilation. Indeed, this pattern is not restricted to the Western colonial experience in Africa, Asia and Latin-America in the last half millennium. It is a feature which is reproduced every time political, economic 
and social hegemony with the attributes of colonialism and overlordship is established on subject peoples. The imposition of the language of the colonizer is the supreme instrument in the effort to control the culture and mind of the colonized. Sowell observes that; '... absorption of the language and culture of the conquerors typically begins with the elite among the conquered peoples, this has created or widened divisions among the indigenous population. Sometimes the division has been not so much by social class as by geographical location, with those located near the foreign cultural centres or spheres of military or economic concentration being the first to absorb the foreign language and culture, with those in the hinterlands continuing the older speech and customs. Thus, in Africa during the era of European colonialism, Africans located in and around the colonial capital, or in the principal ports, would tend to begin speaking English or French, as the case might be, and to become Christians, while those back in the interior busy country retained their indigenous language and indigenous religions' (Sowell 1994:72).

The Romans imposed their culture and educational forms on all the subject peoples and citizens of the Roman Empire (Janson 2012:95). Roman ways were adopted by provincial elites who stood directly in local positions responsible for the maintenance and sustenance of imperial cohesion and Roman ideals (Hingley 2005). The Arab expansion which followed the death of the Prophet in the seventh century AD saw the rapid Arabization of the cultures of subject peoples in the various historical caliphates. The Tsarist Russian Empire likewise extended russification processes to the non-Russian peoples who were brought under its thralldom (Petrovich 1956; and Löwe n.d. $)^{3}$. The religions of the Amerindian indigenes of Brazil were proscribed and

${ }^{3}$ Russian policy towards other nationalities from the time of Catherine II had been mainly directed at eliminating any historical political and social structures which had developed independently from those of the Great Russians and which were different from them, and to replace them with the general structures of the Empire. This policy did continue for some time, although it must be added that the policy was never rigorously applied, nor could it be. At least since Nicholas I another element came into play, whereby many, but not all, peoples were forbidden the use of their language in schools and in the administration. Part and parcel of this policy was, already since Catherine, the mobilization of the Orthodox Church for Russian purposes on the one hand, and on the other an energetic interference in the affairs of other denominations 
these aborigines were coerced to convert to Catholicism. This introduction of Catholicism to indigenous people was culturally traumatic. The genocidal consequences of colonial policies nearly erased all the religious institutions and cultural features of these communities ${ }^{4}$. The Spanish in Latin-America performed their colonial activities in similar fashion. Under Spanish rule, native religion and culture were severely repressed. Whole libraries of native codices were burned by zealous priests who thought that they were the work of the Devil. The Spanish arrived in the Philippines in 1521 and established a colonial foothold in 1565 which lasted till 1898 when American power was established. This lasted till 1935 when it became semi-independent. Under Spanish rule education was overwhelmingly religious/catholic and for the rest concentration was on Spanish grammar. The system was meant to 'keep the natives faithful, in order to keep the church's authority over the lives of the

or religions. Under Alexander II, certainly due to a good degree to his reforms, there appeared for the first time a 'societal' nationalism which, supported by a still very narrow and small public, but at least independent from 'official' Russia, attempted to drive the government towards a nationalities policy, which aimed not only at administrative but also at cultural russification. However, the government deflated such pressure already under the 'TsarReformer' by forbidding or restricting the sphere of activities for nationalist organisations such as the Slavic Welfare Committees

${ }^{4}$ On July 15th, 2015, Survival International reported that; 'Pope Francis has asked forgiveness from the indigenous peoples of Latin America for the many crimes committed by the Catholic church during the "so-called conquest". In an historic speech to the "World Meeting of the Popular Movements" in Santa Cruz, Bolivia, which was attended by many indigenous people, he said: "I want to tell you, and I want to be very clear: I humbly ask your forgiveness, not only for the offenses committed by the Church herself, but also for the crimes committed against the native peoples during the so-called conquest of America". The conquest and the theft of their land led to the genocide of millions of indigenous people who were killed by invaders or died of introduced diseases to which they had no resistance. He acknowledged the depth of suffering by indigenous peoples: "I say this to you with regret: Many grave sins were committed against the native people of America in the name of God.' Pope apologizes for Catholic church's crimes against indigenous peoples"'. 
Indios (colonized Filipinos)' (Sta. Catalina Dacumos). All this was geared towards assimilation. In a proclamation made by US President William McKinley, it was submitted that 'the mission of the US was not to conquer and suppress individual rights and liberties which was recently won by Filipinos from Spain, rather absorb Filipino society into a new culture (i.e. American) as an act of benevolence (kindness) from the American people. In essence just a euphemism, to justify the US colonization of the Philippines' (Ibid). The Japanese came in from 1942 to 1945 and then after the $2^{\text {nd }}$ World War, in 1946 it became independent. During the short period of Japanese colonialism in Korea from 1910 to 1945 the Japanese pursued a slow but systematic assimilation policy ${ }^{5}$. In 1928, as the assimilation policy was accelerated, Japanese administrative policy shifted more aggressively towards cultural assimilation. In 1938 (Naisen ittai - ideology of the unity of Japanese and Korean peoples) was promulgated and by 1943 all Korean language courses had been phased out. The teaching and speaking of Korean was prohibited. Although the Japanese colonial authorities advised further, more radical reform this never came to pass, the defeat of Japanese imperialism ensured that the 10-year plan was never fully implemented (Caprio 2009:155; Prah 2016; and 2017:3). We are informed that in the early 1950s, North Korean writers told our Hungarian diplomats that, 'Japanese language was the most dangerous helper of the expansion of Japanese imperialism,' because Korean schoolchildren 'perfectly learned Japanese as early as the first school year, and the conquerors did their

${ }^{5}$ Following the annexation of Korea, the Japanese administration introduced a free public education system modelled on the Japanese school system with a pyramidal hierarchy of elementary, middle and high schools, culminating at the Keijo Imperial University in Seoul. As in Japan itself, education was viewed primarily as an instrument of 'the Formation of the Imperial Citizen' with a heavy emphasis on moral and political instruction. During colonial times, elementary schools were known as 'Citizen Schools' (gungmin hakgyo) as in Japan, as a means of forming proper 'Imperial Citizens' (Hwanggungmin) from early childhood. The public curriculum for most of the period was taught by Korean educators under a hybrid system focused on assimilating Koreans into the Japanese empire while emphasizing Korean cultural education. This focused on the history of the Japanese Empire as well as inculcating reverence for the Imperial House of Japan and instruction in the Imperial Rescript on Education. 
best to infect them with their propaganda. The Korean language also absorbed countless Japanese words.' I think this cultural shock played a decisive role in the rise of cultural purism in both Koreas' (Szalontai n.d.).

In as far as the cultural denationalization of African societies is concerned the African experience is broadly not dissimilar to the above cases. The creeping recession or effacement of historically indigenous cultural traits, values and institutions, and their replacement by substitutes derived from historically non-African hegemonic cultures and societies of the world is borne by the African experience. For Africans, this process can be traced to the beginning of the Arab conquest of North Africa starting with Egypt ${ }^{6}$. Over the centuries, the process of Arabization has continued uninterruptedly in the

6 The Arabic language became more widespread in Egypt with the introduction of Islam, especially since there was no single Egyptian language. The Coptic language was limited and unofficial, followed by the official Greek language, and then the Arabic language entered Egypt starting in the seventh century AD/ first Century AH. Arabic is a rich and complete language and the people were able to express everything using it. Arabic became the language of the diwan, or council of ministers, and the language of instruction. With the advent of the tenth century AD, fourth century AH, Coptic scholars started to compose theological works in Arabic, which indicates that Arabic had become the prevalent language of scholarship. The Coptic language lost its importance totally during the fourth century AH (tenth century AD), as we find the Coptic books by Said Ibn Al-Batreek and Sawerace Al Ashmoniny were written in the Arabic language although they were intended for a Coptic audience. The spread of Islam and the Arabic language in Egypt was helped by Caliph Abd al-Malik Ibn Marawan's 'Arabization of the Mint and Diwans in the government offices in year $78 \mathrm{AH}$ (697 AD)'. The Copts were forced to learn the Arabic language to keep their jobs in the government offices. Then Abbasid Caliph Al-Mustasim decided to drop Arabization from the government offices. The Arabs and the Copts became equal and the obstacles between the two sides were removed. The Arabs then spread among the Egyptians. Within 400 years, from the Arab conquest of Egypt, Egypt abandoned its national language totally and adopted the Arabic language, while other Muslim countries such as Iran did not give up their national language. (See Spread of the Arabic Language.) 
northern areas of the continent. It is a process which in the past has tended to be overlooked and underestimated by some observers and many students of African history. With regards to the Sudan, Mohammed Jalal Hashim writes that; 'independence, Islamization and Arabization have been shared in common by successive governments as state-dictated policies. Taking for granted that the middle of Sudan represents the whole country prompted this. The post-Independence governments dealt with the Sudan as consisting of (a) the noble Arabs of the middle, (b) the Muslim Africans in the periphery, who, with possible Arab blood, are supposed to undergo very quickly the process of Arabization so as to be honoured with Arabism, and (c) the slaves, who have not yet undone their black Africanism with Islam and a drop of noble Arab blood and who have no place so far in the bench of power. ...' (Hashim 2009). This reality has in no small measure been responsible for much of the current tensions and conflicts which have beset the Sudanese state since 1955. AfrikNews of the $13^{\text {th }}$ April, 2010, in an article headed; Mauritania: Arabization has nothing to do with Islam divulged that; 'The Mauritanian government, .... spoke out on the burning issue of Arabization, which was raised by the Prime Minister and Minister of Youth and Culture on March $1^{\text {st }}$. Arabization in Mauritania has whipped up a massive hue and cry among Negro-Mauritanians, who have expressed concerns over cultural, political, economic and social oppression from the ruling Arabo-Berbers. Mauritania, a generous cultural and linguistic patchwork has, since March, fallen prey to the discontentment of a key section of its Black Mauritanian populations, who have demonstrated their displeasure against their government's intention to Arabize the administrative and educational sectors. Those arguments were strongly denied .... 'Nothing has changed, Mauritania before $1^{\text {st }}$ March remains the same, the government has not opted for a complete Arabization,' the Minister of Higher Education, Ahmed Ould Bahya told a large number of students gathered at the University of Nouakchott. His statement comes after two controversial speeches made by the Prime Minister, Mohamed Ould Moulaye Laghdaf and Minister of Youth and Culture, Cissé Mint Boide, March $1^{\text {st }}$, a day set aside to commemorate the promotion of the Arabic language, under the theme; 'Arabic language is the language of our religion and our identity'. 'Mauritanian civilization is AraboIslamic!' the Minister of Youth and Culture had added. These comments, deemed segregationist, shocked and sent emotions among Black Mauritanians running amok. Placards read; 'No to complete Arabization', 'No discrimination!', 'We are all equal!' as students demonstrated on March $25^{\text {th }}$ and April 
$6^{\text {th }}$. 'Mauritania's peaceful future can hardly be reassured if these contradicttions are not satisfactorily resolved. Furthermore, given the dimensions of the inherent tensions, consequent conflicts cannot be contained within the borders of the country. In the whole latitudinal area running from Mauritania to the Sudan, Arabization has continued for centuries to erode the African cultural and social attributes of the native peoples. The Berber were in this part the first to be Arabized. They subsequently in part became instruments for the further Arabization of other groups in the region. In the whole region resistance to Arabization continues. The later arrival of the West effectively superseded Arab influence, but never completely halted the expansion of Arabism.

Western conquest and the establishment of Western power opened the door to the institution of Western administration, Western education, the introduction of Western Christianity and the imposition of colonial languages as elite reference group attributes. In our times, this process is captured in the notion of globalization in a cultural sense, and is at least in Africa, accelerating at a pace which would suggest that unless the process is checked, so that Africans regain the core features of their languages, cultures and histories, the cultural effacement of Africans may reach a point of no return. This denationalization process has affected all areas of social life, including, the religious life and lore of Africans, languages, modes of livelihood, consumptive patterns, values and normative structures. Today, its main agents on the ground are the African elites.

The upshot of these examples is that, imperialism and its colonial manifestations always imposes cultural and educational co-optations and assimilation strategies on subject peoples. It is thus no surprise that Western colonialism in Africa has borne the universal markings of imperial history in the area of education and culture. Cultural erasure of memory and denationalization has been the hallmark of colonialism in Africa and elsewhere. The challenge we face is that, what do we do to create correctives which will enable us to emancipate African societies in order to be able to improve the existential conditions of Africans? What can we learn from such historical cases?

\section{Colonial Education and Acculturation in Africa}

During the colonial period, the language policies in education, followed closely the broad imperial tenets espoused by the different colonial powers. The 
colonial powers educated Africans and Asiatics, primarily with the object of creating a class of natives who could serve as a bridge into wider native society for the purposes of the colonial powers and colonial administration; a social element moulded through formal education to enable access and engagement with mass society. These elements acquired a level of assimilability and affinity to the Western mind and the service of imperial intent. The educational process was meant to produce elements who would serve as compliant cogs in the colonial structural machine; a machine intended to, firstly, serve the larger interests of the colonizer. While this was the broad thrust of the approach, there were differences between British, French and Portuguese approaches to colonial education in Africa in general, and the use of language in education in particular.

The British, wanted to create African cadres who would serve as interlocutors between colonial administration and mass society, but who were sufficiently educationally anglicised, and who would be able to play complementary roles in the establishment of the British power in Africa. They made greater, if grudging, use of the indigenous languages. The French went further towards the reproduction of themselves and attempted to make black Frenchmen (citizens of France) out of Africans and therefore applied a policy of, more or less, zero tolerance to African languages in education. The British view was that education should begin in the African languages for the first very few years and then branch out into the use of English. In practice, in British colonial Africa, very limited resources were put into early education in African languages. The French, anxious to make Frenchmen and women out of Africans preferred from the start to favour almost total immersion except in the 'initiation schools' which provided limited early primary education in African languages. The Portuguese were the most hard-nosed in this colonial policy of cultural and linguistic de-nationalization ${ }^{7}$. When the French educated Africans

${ }^{7}$ Angola, Decree 77 of 1921, required that all missionaries in Angola had to be bona fide ministers of religion and not laity; they were obliged to teach exclusively in Portuguese and not in any other foreign tongue; they were proscribed from any indulgence in commerce of any sort and were not to print, write or teach any African language except at the level of catechism classes. In Mozambique where Protestant missionaries had permanently entered in 1879, Mozambican languages had been taught almost uninterruptedly for years and this had been instrumental in the creation of a small literate group in the 
to read and accept the idea of 'nos ancêtres les Gaulois,' (our ancestors, the Gauls) they were systematically undermining not only the primacy of the African language to the African but even more seriously, effacing the identity of the African and replacing it with a mythology of Frenchness. Therein, lies the foundation of the confusion which present-day francophone and francophile elites in Africa still carry.

Thus education under colonialism created an elite culturally oriented towards Western society and values, and psychologically determined to be as quickly as possible removed from the culture and roots of pre-western Africa (or mass society). The educated or so-called civilized African became assimilé in the French system, evolué in the Belgian order and an assimilado in the Portuguese empire. In KiSwahili, ista arabu, literally becoming Arabized means, becoming civilized. Literally, he or she had evolved from primitivism, or been assimilated into 'civilized culture.'

\section{Language and Education}

Post-colonial Asia for a large part has dismantled the cultural, particularly linguistic element of the colonial legacy. Nowhere in former colonial Asia was the language of the colonizer elevated in the post-independence order to the status of a national language. This reality contrasts fairly sharply with the records of the large majority of the former colonies in Africa and the Western hemisphere which have opted for the languages of their erstwhile masters. The explanation for this historical difference lies in the fact that in Asia the colonized societies were societies with highly developed indigenous cultures, with extended historical ties to the literate religions and age-old written traditions. It has been particularly these traditions of literacy and associated lore that have served as innate protection and inherent resistance to the neocolonial burden of the language and cultural baggage of the colonizer (see Prah 2009:83 - 104; Groeneboer 1998:14; and Goody 1989:86).

Be that as it may, at least for the present, African post-colonial elites, unlike the Asian cases, have consistently demonstrated an inability to shake off this colonial hangover of overwhelming cultural dependency in particularly the

\footnotetext{
African languages in the extreme south of the country on the eastern lakeshore of Lake Malawi. But again here, 1921 saw the banning of the use of African languages in education.
} 
linguistic front. Time and again, we display the fecklessness and ineffectuality to protect and defend our larger social interests. In Rwanda, since 2008 English has been adopted as official language and language of instruction in schools. The supposed reasoning behind this is not only economic but also political (see Plonski, Teferra \& Brady 2013). An observer noted that; 'the shift to education solely in English is part of a wholesale realignment away from French influence that includes applying to join the Commonwealth - if accepted Rwanda would be only the second member, after Mozambique, that has not been a British colony ...' (McGreal 2008). Subsequently, the subject was featured again by the same newspaper; The Guardian (UK) of 13 November 2012, that; Gabon says that it is considering following Rwanda's example by dropping French in favour of English. Evidence of the success of this education policy is wanting. A spokesperson for the president of Gabon announced that, the country which uses French as its official language, was considering following the example set by Rwanda by shifting from French to English. 'Rwanda has claimed that economic gain motivated its 2008 decision to downgrade French, the language it inherited as a Belgian colony. By converting to English-medium teaching in the majority of its schools, its leaders say it is attempting to produce a generation with a grasp on the linguistic key to global trade and business' (Clover 2012). Recently (2017) in Cameroon people have been banned from watching a popular television station that it claimed represents the interests of the English-speaking population. The British Broadcasting Corporation (BBC) News reported that cable television providers have been told they will be sanctioned if they do not stop broadcasting the South Africa-based channel, Southern Cameroons Broadcasting Corporation (SCBC). However, it can still be viewed online. The report went on to explain that, for months, there have been protests by Cameroon's Anglophone population against what they say is discrimination by the Francophone majority. Some pro-English activists have been accused of campaigning for a separate country. SCBC runs programmes about the history and culture of the Anglophone region, as well as interviews with exiled lawyers and documentaries about human rights abuses in Cameroon ${ }^{8}$. Aljazeera wrote

${ }^{8}$ Cameroon: 'Pro-English' television channel banned. Monday 04 September 2017. Legalbrief Africa. Issue No: 741. IBA. See also: Cameroon bans 'opposition' English-language TV channel. BBC News. 30 August 2017. Available at: http://www.bbc.com/news/world-africa-41094096. 
that ( $1^{\text {st }}$ October, 2017) troops have been 'deployed to Anglophone regions as activists declare symbolic independence from country's French-speaking areas' (Essa 2017).

Almost two years ago, $\left(13^{\text {th }}\right.$ November, 2015) the Mail and Guardian (South Africa) reported that; 'Student pressure group had protested against use of Afrikaans as official teaching language, saying it disadvantaged blacks ... After months of turmoil at South African universities, student protesters have won the right to be taught in English at Stellenbosch University, the intellectual home of Afrikaners during apartheid. ... It was the latest victory for increasingly militant students who complain that the country's universities remain racist 21 years after the first democratic elections brought Nelson Mandela to power' ${ }^{\text {. }}$. Surprisingly, these predominantly, African languagespeaking students were oblivious about the need for mother-tongue languages of instruction.

During the past century, the pre-eminence of English has steadily swept a good part of the world and tended to strengthen the illusion that there is an inherent superiority of English which makes it increasingly the global language of choice. This is in fact far from the truth. It is the global ascendancy of English language-based power and culture of the United States of America, the global super-power of our times, which buttresses the position of British English and is responsible for the currently unrivalled supremacy of the English language. This position is aided by the linguistic cultures of the erstwhile British empire, the English-speaking nations; Canada, Australia, New Zealand, plus the former colonies in Africa, Asia and the Caribbean. The portent of English language universalism threatens even developed European languages like Dutch, French, German, Norwegian, Swedish and Danish in their backyards. Some scholars and observers like Birgit Brock-Utne, Per Ake Lindblom, Paul Thomas, Anders Breidlid and Tan Tanali have signalled growing disquiet with this emergent phenomenon, where at the tertiary level market forces are increasingly opening up influential space for English language of instruction (See Brock-Utne 2009:275-282; Lindblom 2009: 283288; and Tunali 2017. Breidlid and Thomas call it the 'Anglobalization of

${ }^{9}$ Stellenbosch University students win right to be taught in English. The Mail and Guardian (South Africa). 13th November, 2015. Available at; https://www.theguardian.com/world/2015/nov/13/stellenbosch-universitystudents-protest-english See also Spaull and Shepherd (2016). 
Education.' A phenomenon 'spurred on by the Europe-wide commodification of education in English' (Thomas \& Breidlid 2015:349-368).

Here in South Africa, what many of us fail to see is that the technological and scientific aptitude of the society plus the processes for the production and reproduction of knowledge are located in the two white minority cultures, English and Afrikaans. All products and production which require any scientific inputs are done in English and Afrikaans. The cultures and languages of the African-language speaking majorities are completely out of the question. African language-speakers are only consumers. Culturally as Africans, we contribute nothing scientific or technologically innovative, we contribute only labour to production in society. This is also true for the whole of Africa. The extraordinary development of Afrikaans should be a lesson for all Africans. The rapid Afrikaner language development example demonstrates that it is possible over a relatively short period of time to develop a language to become a language for science and technological progress; an empowered language for educational purposes capable of carrying knowledge at advance modern levels.

In 1976, the dogged racist arrogance of the Afrikaner nationalist power elite's effort to boldly and ruthlessly impose Afrikaans on African school children finally provoked sharp resistance in Soweto. These schoolchildren rejected with determination the imposition of the 'language of the oppressor'. Paradoxically, Afrikaner history is replete with their own earlier rejection of the imposition of English throughout most of the $19^{\text {th }}$ century. This latter had indeed been the linguistic and wider cultural dimension of the Anglo-Boer conflict. English and Afrikaner cultural and linguistic contestation had been continuous from the earliest years of Western settlement.

The first of the settler language policies was outlined under the governorship of Simon van der Stel (1679-1691). It was instituted soon after the arrival of the French Huguenots in the Cape in 1685. The first school which was created for Huguenot children (1688) utilized a bilingual French/Dutch teacher. Two years later, it was decided that Dutch should be the language of instruction for both French and Dutch children. Dutch language use became well-established. Much later, Sir John Cradock (1811-1814) introduced an Anglicisation policy which was further consolidated by Lord Charles Somerset (1814-1826). In 1822 he decreed that English should be the official language of the Colony. In 1879, the De Villiers Commission of Enquiry into Schooling, advocated that the English should be required to learn Dutch to ensure a more 
balanced cultural atmosphere (Le Roux 2016). Between 1897 and 1901, Alfred Milner as High Commissioner for Southern Africa and Governor of Cape Colony pursued an undivided policy of Anglicization of Afrikaners. He saw demographic engineering in favour of English speakers as the most assured route to Anglicization. Second to this was education. His policy was that; 'Dutch should only be used to teach English, and English to teach everything else ${ }^{10}$. The Treaty of Vereeniging (1902) ${ }^{11}$ which ended the $2^{\text {nd }}$ Anglo-Boer war followed a decade later by the Act of Union (1910) opened with speed the door to the emergence of Afrikaans from the shadows, into societal equality with English. The Afrikaans standard orthography was finalized in 1913 and that same year it was introduced to primary schools. It was introduced at university level in 1918. 1925 saw its usage in Parliament. The Afrikaans Bible was out in 1933. Beyond that time, Afrikaans as a language became technically equipped to deal with the production and reproduction of knowledge as any in the world. The development of Afrikaans from standardization of the orthography to the technical equipment of an intellectualized language took about 25 years, the same distance in time we have travelled from the end of Apartheid to the present. Similar feats have been achieved for Modern Hebrew and Bahasa.

\section{Closing Observations}

The foundation on which culture is built and transacted is language. Language captures the experience of its users, and serves as the key depository of the collective experience of its producers. It is in language that the creativity and innovative traditions of its creators and users are institutionalised, and it is within language that the processes of the production and reproduction of knowledge are effected. The development and usage of African languages for all social transactions including education are the only way of ensuring the cultural empowerment of mass society in Africa. It is only through the usage

${ }^{10}$ A. Milner is quoted here from; Mueni Wa Muiu (2008:58).

11 The significance of the language question for the Afrikaners was underscored by the fact that, urging his fellow Afrikaner leaders to accept the terms of the peace, Louis Botha argued: 'Terms might now be secured which would save the language, our ancient customs and national ideals. The fatal thing would be to secure no terms at all and yet be forced to surrender'. 
of African languages in education that knowledge can be channelled into the cultures of the overwhelming majorities of Africa, in ways which will ensure their confident usage and understanding by Africans. An enabling condition is that African languages need to be literate and intellectualized. The upshot of the logic of this argument is that, an African renaissance will be only possible if the processes for this are premised on the untrammelled usage of African culture, more specifically African languages. 'No country can make progress on the basis of a borrowed language' ${ }^{\text {' }}$.

If transformative education and development must come to Africa it must come in the cultural features of Africans; it must come in African languages. We need to be reminded that no language is from Adam a language of science and technology. Languages become modern and scientific in their competence because people decide to make them so and push into them the requisite resources to make them so. In the UNESCO Report of the Commission on Culture and Development (1995) the point is adequately made that; 'All languages are equal in the sense that they are an instrument of communication and every language has the same potential as a world language. The realization of this potential depends on the opportunities it is given. It was once believed that languages are like living creatures; they are born, grow, decline and die. This picture is false. Languages are wholly both instruments for and results of the societies in which they are used, or abandoned. The fate of all languages is the result of the social and political environment, above all of power relations ${ }^{\prime 3}$. We need to terminologically equip our languages to embrace modern science and technology; that is essential to the work of intellectually extending the frontiers of African languages to embrace modernity.

The decolonization of education must start with the re-centering of African languages in the heart of our educational endeavours. Without this, the decolonization of education will remain empty, unrealizable verbiage.

\section{References}

Bodmer, F. 1943. The Loom of Language. London: George Allen and Unwin.

${ }^{12}$ Interview of K.K. Prah by Alicia Mitchell in eLearning Africa Report (2013). 13 'Our Creative Diversity’ (p. 179). 
Brock-Utne, B 2009. Is Norwegian Threatened as an Academic Language? In, Brock-Utne, B. \& G. Gunnar (eds.): Language and Power. Dar es Salaam: Mkuki na Nyota Publishers.

Cameroon: 'Pro-English' television channel banned. Monday 04 September 2017. Legalbrief Africa. Issue No: 741. IBA.

Cameroon bans 'opposition' English-language TV channel. BBC News. 30 August 2017. Available at: http://www.bbc.com/news/world-africa-4109 4096.

Caprio, M.E. 2009. Radical Assimilation under Wartime Conditions. Japanese Assimilation Policies in Colonial Korea, 1910-1945. University of Washington Press.

Chomsky, N 1975. Reflections on Language. New York: Pantheon Books/ Random House.

Clover, J. 2012. Jury out on Language-switch Trend. The Guardian (UK).

13.11.2012. Available at: https://www.theguardian.com/education/ 2012/nov/13/rwanda-english-language-lessons.

Engels, F. [1876] 1950. The Part Played by Labour in the Transition from Ape to Man. New York: International Publishers.

Essa, A. 2017. Cameroon's English-speakers Call for Independence. Al Jazeera News. 1.10.2017. Available at: http://www.aljazeera.com/news/ 2017/10/171001123925310.html.

Goody, J. 1986. The Logic of Writing and the Organization of Society. Cambridge: CUP.

Groeneboer, K. 1998. Gateway to the West: The Dutch Language in Colonial Indonesia. 1600-1950. A History of Language Policy. Amsterdam: University of Amsterdam Press.

Hingley, R. 2005. Globalizing Roman Culture: Unity, Diversity and Empire. London and New York: Routledge \& Taylor and Francis Group.

Horne, D. 1969. God is an Englishman. Sydney: Angus and Robertson in Association with Penguin Books.

Jalal Hashim, M.J. 2009. Islamization and Arabization of Africans as a Means to Political Power in the Sudan. Mimeo. July, 2009. Available at: http://mjhashim.blogspot.com/2009/05/islamization-and-arabizationof.htmlJanson, T. 2012. The History of Languages. Oxford: OUP.

Le Roux, C. 2016. Creating a British World: British Colonial Teachers and the Anglicising of Afrikaner Children. Yesterday and Today No.15. Vanderbijlpark, July. Publication of the South African Society for History 
Teaching. Available at: http://dx.doi.org/10.17159/2223-0386/2016/n1 $5 \mathrm{a} 1$.

Lindblom, P.A. 2009. Are Nordic Languages Threatened as Academic Languages? In Brock-Utne, B. \& G. Gunnar (eds.): Language and Power. Tanzania: Mkuki na Nyota Publishers.

Löwe, H-D n.d. Russian Nationalism and Tsarist Nationalities Policies in Semi-Constitutional Russia, 1905-1914. Seminar für Osteuropäische Geschichte. Available at: http://www.uni-heidelberg.de/fakultaeten/ philosophie/zegk/sog/loewe_artikel_russian.html

McGreal, C. 2008. Rwanda to Switch from French to English in Schools. The Guardian (UK). 14 ${ }^{\text {th }}$ October, 2008. Available at: https://www.the guardian.com/world/2008/oct/14/rwanda-france.

Petrovich, M.B. 1956. The Emergence of Russian Panslavism, 1856-1870. New York

Plonski, P., A. Teferra \& R. Brady 2013. Why are More African Countries Adopting English as an Official Language? Paper presented at African Studies Association Annual Conference, November 23, 2013. Baltimore, Maryland. Available at: https://www.booksforafrica.org/assets/docu ments/2013-ASA-Conference---English-Language-in-Africa-PAPER.

Pdf.

Prah, K.K. 2009. Mother-tongue Education in Africa for Emancipation and Development: Towards the Intellectualization of African Languages. In Brock-Utne, B. \& I. Skattum (eds.): Languages and Education in Africa: A Comparative and Transdisciplinary Analysis. Oxford: Symposium Books.

Prah, K.K. 2013. Interview of K.K. Prah by Alicia Mitchell. No Country can Make Progress on the Basis of a Borrowed Language. ELearning Africa News. Perspectives on ICT, Education and Development in Africa. eLearning Africa Report 16 May, 2013. Available at: http://elanewsportal.com/no-country-can-make-progress-on-the-basis-of-a-bor rowed-language/.

Prah, K.K. 2016. Towards the Intellectualization of African Languages: Lessons from Asia. Lecture 1 (18th May 2016). University of Venda \& CASAS Publication.

Prah, K.K. 2017. Creating Knowledge in Africa. School of Human and Social Sciences Annual Lectures. University of Venda. 18th - 20th May, 2016. Cape Town: CASAS Monograph Series, No. 265. 
Prah, K.K. 2017. Has Rhodes Fallen? Decolonizing the Humanities in Africa and Constructing Intellectual Sovereignty. The Academy of Science of South Africa (ASSAF) Inaugural Humanities Lecture. Pretoria: HSRC. 9th March 2017. Available at; www.hsrc.ac.za/.../Has\%20Rhodes\%20 Fallen.docx\%20ASSAF\%20Address\%2015.2.2...

Sowell, T. 1994. Race and Culture: A World View. New York: Basic Books \& HarperCollins.

Spaull, N. \& D. Shepherd 2016. Afrikaans Varsities Perpetuate Racial Divisions. The Mail and Guardian (South Africa). 4th March, 2016.

Spread of the Arabic Language. Available at: www.eternalegypt.org/Eternal EgyptWebsiteWeb/HomeServlet?ee_website_action_key=action.display. module\&story_id=\&module_id=234\&language_id=1\&text=text.

Sta. Catalina Dacumos, R. Philippine Colonial Education System. Available at: https://www.researchgate.net/publication/280610684_Philippine_Col onial_Education_System.

Stellenbosch University students win right to be taught in English. The Mail and Guardian (South Africa). 13th November, 2015. Available at: https://www.theguardian.com/world/2015/nov/13/stellenboschuniversity-students-protest-english.

Steiner, G. 1970. Language and Silence: Essays on Language, Literature and the Inhuman. New York: Atheneum.

Survival International 2015. July $15^{\text {th }}$. Available at: https://www.Survival international.org/news/10845.

Szalontai, B n.d. Japan-Korea, France-Algeria: Colonialism and Language Policy. Available at: http://koreanstudies.com/pipermail/koreanstudies_ koreanstudies.com/2013-October/023011.html.

Thomas, P. \& A. Breidlid 2015. In the Shadow of 'Anglobalization' National Tests in English in Norway and the Making of a New English Underclass. Journal of Multicultural Discourses 10,3: 349-368.

Tunali, T. 2017. Het Engels is zo'n extraatje. De Groene Amsterdammer. 6th September 2017.

Tunali, T. 2017. Keert de academie haar rug naar de Nederlandse samenleving? Steeds vaker schakelen Nederlandse universiteiten over op het Engels in hun slag om de buitenlandse student. Keert de academie daarmee haar rug naar de Nederlandse samenleving?

Wa Muiu, M. 2008. The Pitfalls of Liberal Democracy and Late Nationalism in South Africa. New York: Palgrave Macmillan. 
World Commission on Culture and Development 1996. Our Creative Diversity. Paris. Available at: http://unesdoc.unesco.org/images/0010/ 001055/105586e.pdf.

Kwesi Kwaa Prah

Centre for Advanced Studies of African Society (CASAS)

Cape Town

kkprah@casas.co.za 